This is the author's version of a work that was accepted for publication in International Journal of Educational Development. Changes resulting from the publishing process, such as peer review, editing, corrections, structural formatting, and other quality control mechanisms may not be reflected in this document. Changes may have been made to this work since it was submitted for publication. A definitive version was subsequently published in International Journal of Educational Development Vol 39, November 2014. doi:10.1016/j.ijedudev.2014.08.004

Article published as:

Singh, Renu and Colin Bangay (2014) 'Low fee private schooling in India - More questions than answers? Observations from the Young Lives longitudinal research in Andhra Pradesh', International Journal of Educational Development 39: 132-140. doi:10.1016/j.ijedudev.2014.08.004

The article is reproduced in accordance with the self-archiving policies of Elsevier. 


\title{
Low Fee Private Schooling in India -More Questions than Answers? Observations from the Young Lives Longitudinal Research in Andhra Pradesh
}

\author{
Renu Singh \& Colin Bangay
}

\begin{abstract}
This paper seeks to draw attention to two important, but less researched areas regarding low fee private school provision in India. Firstly, the paper evaluates the impact of fees on household debt burden and decision making; and secondly highlights the dynamic interplay between the private and government sub-sectors and the potential consequences this may have for educational delivery. The paper attempts to provide an overview of the historic growth, extent and performance of low fee private schools and private tutoring. Consistent with others, the paper finds that private provision is not currently accessible to the poorest and thus potentially deleterious to equity both within schools and within families. While drawing on existing research and particularly the longitudinal Young Lives data sets in Andhra Pradesh - findings are largely exploratory. The paper concludes that there is a need for further research on both household and school effects related to increasing privatisation in education. In particular there is a focus on how emerging inequalities emanating from school choice and private tuitions can be addressed. This is urgently needed to inform policy and investment decisions that maximise the contribution of both sectors and mitigate against inequality.
\end{abstract}

\section{Keywords}

Private Schools; India; Equity; Debt Burden; Tuitions.

\section{Introduction}

In the last decade, India has made dramatic progress on school enrolment. According to the Global Monitoring Report 2012, India is one of the top performers -with 18 million fewer children out of school in 2008 than in 2001 (UNESCO 2012 ). Initiatives such as the governments national programme Sarva Shiksha Abhiyan (SSA), the school meals programme and as of 2010 the Right to Education Act (Ministry of Human Resource Development, 2013; Noronha and Srivastava, 2012) have put India on track to achieve Millennium Development Goal(MDG) two enrolment (Little 2010), and MDG three gender 
equity (De,2011; UNICEF, 2011). Despite this impressive expansion, worryingly low levels of learning are causing major concern (Chavan \& Bannerjee, 2012; Pritchett and Beatty, 2012). Data suggests growing numbers of parents are turning from free government provision and sending their children to low fee private schools ${ }^{1}$. Estimates of the balance in provision between sub-sectors and speed of change vary. While official data suggests some $20 \%$ of enrolment is in private schools (NUEPA 2011), on the other hand ASER reports that since 2009 , private school enrolment in rural areas has been rising at an annual rate of about $10 \%$. ASER (2012) projects that if this trend continues; India will have 50\% children in rural areas enrolled in private schools by 2018. While in a country as large and diverse as India it would be expected that the scale, speed and nature of changes in provision between government and private will vary both within and across states - this paper is premised on an acceptance that substantive movement of students into private schooling is occurring. On this basis this paper sets out to review two questions. Firstly, what are the implications of the movement of children to private schools for household expenditure, debt burden and family decision making? Secondly, what may be the effects and implications of this migration on how government schools operate? In doing this we draw on evidence and in particular the data and work of the Young Lives ${ }^{2}$ team in Andhra Pradesh (now bifurcated into two states of Telengana and Andhra Pradesh), India. Our findings suggest that a better understanding of household expenditure on education and the dynamic between private and government schooling (i.e. the influence they have on each other) to be a critically important for future policy development. In writing this paper, we caution that we are working with a limited evidence base. As such the paper concludes with some recommendations for future research and how Young Lives seeks to pursue this critical but unexplored area in the near future.

\section{Part One: Private Schooling in India - The Existing Literature}

\section{Private Schooling: Definition, Reporting and Distribution}

\footnotetext{
${ }^{1}$ These are different from the elite private schools and are mainly located in slums and small habitations. The fee can be in the range of Rs 50 per month (less than $\$ 1$ ) to Rs $600 /$ - per month ( $\$ 10$ approximately)

${ }^{2}$ Young Lives is a longitudinal study of child poverty which follows cohorts of children in four countries: Ethiopia, Andhra Pradesh state (India), Peru and Vietnam. It is funded by the UK and Netherlands government and executed through collaboration between Oxford University and Save the Children. For details, please visit www.younglives.org.uk
} 
The challenge of defining what constitutes a private school (as opposed to a non-state school) has to date depended on rather blurred descriptors. Typically these have relied on locating schools within a matrix defined by two common characteristics namely the degree of government influence/control and financing approach (Bangay, 2007). While it is clear that there is diversity in the nature of 'private schools' in India (as elsewhere) - it is possible to apply a definitive criteria - i.e. that a private school is one that is reliant on a user fees element for its financial sustainability. In discussing low fee private schools (LFPS) in this paper we are referring to small often family run enterprises which cater for the poor and are dependent on fees for their operation (Srivastava, 2007). By official Indian categorisation these equate to- private, unaided, and in some cases unrecognised schools.

Indian official statistics delineate three main types of schools: government, government aided and private unaided schools (either recognized or unrecognized). Official government statistics report that $20 \%$ of all schools are under private management (DISE 2010-11); while the latest national household survey data reports $7 \%$ of India's students attend private aided and $20 \%$ private unaided at primary level (grades I-V / ages 6-11) and 12\% and 17\% respectively at elementary level (grades VI to VIII / ages 12-14) (National Sample Survey, 2009). Government data is likely to be under reporting the real extent of private school enrolment, for two-fold reasons. Firstly, hand government enumerators do not collect data on unrecognised private provision and this is further combined with the fact that unrecognised private school owners wish to remaining 'off radar', thereby avoiding unwanted attention from rapacious officials (Tooley and Dixon, 2003). By way of illustration, Kingdon (2007) found $20 \%$ of children in rural areas attended private schools, three times higher than the official government statistics. Further, a large scale survey of 20 Indian states, revealed that $51 \%$ of all private rural primary schools were unrecognized (Muralidharan \& Kremer, 2006). Notwithstanding the caveat of official figures only registering recognised private schools, official data clearly shows the growth of the private sector enrolment both in absolute numbers and as a proportion of total enrolments (Figs $1 \& 2$ ).

\section{Figure 1: Enrolment in Private and Public Schools in India}

Figure 2: Percentage of children attending private school (primary level) with projections based on current trends 


\section{Learning Performance}

The majority of studies that have compared student learning performance in Indian government and private schools do show a 'private school premium' even after accounting for student effects. A range of econometric techniques have been applied to correct for possible biases: by controlling for observed background characteristics of children (Muralidharan and Kremer, 2006; Wadhwa, 2009; Goyal, 2009; Goyal \& Pandey, 2009; Govinda \& Varghese, 1993; Kingdon, 1996; French and Kingdon, 2010; Desai et al, 2008); using lagged test scores and community fixed effects (Singh and Sarkar 2012); by running models with village fixed effects to isolate village level confounders; through household fixed effects (e.g. French and Kingdon, 2010); through propensity score matching (Chudgar and Quin, 2012); and finally, through the use of Heckman selection models (Kingdon, 1996; Desai et al, 2008). It is however important to note that these studies only highlight relative performance - with low fee private schools frequently only being marginally better than what are often poorly performing government schools . Overall the levels of learning reached in both school types are worryingly low (ASER, 2010, 2011, 2012). The poor levels of reading are a concern (Fig 3), while even some of India's 'high end' private schools struggle to establish foundational mathematical concepts and are dominated by rote learning (Education Initiatives 2006, 2010).

Figure 3: Trends Over Time: \% Children in Std III who CAN READ Std I level text By school type (2009-2012)

\section{Parental Decision Making and the Choice of Schools}

Stern \& Heyneman (2012) suggest that non-government schools have proliferated developing countries, in order to meet excess demand resulting from an insufficient supply of public school spaces and/or to provide alternatives to a failing public education system. The movement of students into private schools in India appears driven by both push and pull factors. Key elements seem to be firstly; dissatisfaction with the government school particularly in relation to teacher attendance and behaviours (Harma, 2011) and secondly; a preference for English medium instruction (often government schooling is delivered in the 
official state language) and the perceived prestige and wage advantage English is perceived to deliver (Nilekani, 2010; Aslam et al, 2010; De et al, 2002). Interestingly, while Harma, 2011 reported that the majority of parents in her study in Uttar Pradesh stated their preferred school type was a LFPS, she also found that sample parents viewed private schools as preferable only while government schools are failing. Furthermore, there was distrust in private institutions which could change their fees or shut down at any time.

\section{Part Two: Emerging Evidence from Young Lives in Andhra Pradesh}

In the following section we explore the issues of school choice in terms of its impact at source - i.e. household level, and destination - school and school system level. We do this using quantitative and qualitative data generated by the Young Lives longitudinal study being conducted in Andhra Pradesh (AP). ${ }^{3}$

The state of AP is located in the South East of India. It has a population of over 80 million (roughly the size of Germany); 73\% of which live in rural areas. AP is ranked 14 out of 35 states and Union Territories on the composite educational development index (DISE, 2009/10). Given the size and diversity of India there are always dangers in extrapolating findings to a national context. While national household survey data indicates that AP is experiencing a more rapid movement of students to private schools than the national average (Fig 4); we believe the Young Lives work is sufficiently robust and analogous to wider trends to shed light on the low fee private school phenomenon and particularly its possible impacts at family and school and school system level.

\section{Figure 4: Enrolment Share in Private Education}

\section{About Young Lives and Andhra Pradesh}

Young Lives is a fifteen year longitudinal study on the impact of poverty in children's lives ${ }^{4}$. The study tracks individuals from child to adulthood providing unique opportunities to explore interrelated factors that impact on this journey in four countries: India, Peru, Ethiopia and Vietnam. Young Lives data is open access and secondary data analysis is positively

\footnotetext{
${ }^{3}$ As of June, 2014 the state of Andhra Pradesh has been bifurcated into two states- Telengana and Andhra Pradesh.

${ }^{4}$ Young Lives is core funded by funded by DFID and Government of Netherlands and is led by a team in Department of International Development, University of Oxford
} 
encouraged. ${ }^{5}$ Young Lives study in AP has tracked two cohorts of children beginning in 2002, revisiting the same children every three years and the fourth survey round has recently been completed in 2013. This longitudinal approach enables investigation of change over time within cohorts and comparison of changes between different age cohorts.

The Young Lives India sample consists of 3,000 children; 2,000 in the younger cohort (YC) and 1,000 in the older cohort (OC). Children (roughly equal numbers of boys and girls) have been randomly selected from 98 communities located in 20 urban and rural sites, situated across seven of AP's districts. The sampling methodology adopted by the Young Lives team in Andhra Pradesh is known as a sentinel site surveillance system. It consisted of a multistage, purposive and random sampling to select the two cohorts of children. Young Lives' sentinel site sampling includes 15 rural sites distributed across the state plus five urban sites (including the capital, Hyderabad). This methodology selected households at random within a study site, while the sites themselves were chosen on the basis of predetermined criteria, informed by the objectives of the study. ${ }^{6}$ Comparison with National Household Survey Data (DHS 1998/99) for AP indicates that YL sample is broadly representative (Kumra, 2008). Young Lives data has been collected through interviews with children and their families through four rounds of household surveys conducted in 2002, 2006, 2009 and 2013. The questionnaires include information on school type as well as perception of quality of schools attended.

This paper draws on Round 3 household and educational data pertaining to both YC and OC children based on 2905 households, as well as qualitative survey. Three rounds of Young Lives qualitative surveys have been conducted in 2007, 2008 and 2010 and in-depth individual interviews with parents and children of a sub-set of 48 YL children, along with focus group interviews with key stakeholders as well as participatory group exercises with children have been undertaken in four $\operatorname{sites}^{7}$. A qualitative sub-study was conducted particularly to understand reasons for parents' choice of schools in 2010-11.

Longitudinal analysis of three rounds of Young Lives data reveals that in 2009-10 almost the entire sample of 8 year old younger cohort children was enrolled in school, while enrolment for older cohort at age 15 years has decreased by 12 percentage points as compared to enrolment at age 12. In short, almost 25 per cent of the girls and 20 per cent of

\footnotetext{
${ }^{5}$ See http://www.esds.ac.uk/international/access/133379.asp for accessing open source data

${ }^{6}$ For more details on sampling rigour please refer to Technical Note 2 (Kumra, 2008) Source: http://www.younglives.org.uk/publications/TN/assessment-young-lives-sampling-approach-india 7 Two rural ,one urban and one tribal site -Poompuhar, Katur, Polur and Patna
} 
the boys aged 15 years had dropped out-of-school by the time they reached junior secondary school age (Table 1).

Table 1: Young Lives Andhra Pradesh - School Enrolment by Cohort across Rounds

\section{Part Three:}

\section{Implications at Destination: Potential Systemic Implications for Educational Provision} Overall Trends

At macro level Young Lives findings are consistent with those of others in indicating a substantial movement of students from government to private schools. Analysis of the Young Lives round three survey report (Galab et al, 2011), shows that the number of eight year olds going to private school nearly doubled from 24 per cent in the OC (children born in 1994-5) in 2002 to 44 per cent in the YC (children born in 2001-2) in 2010. Disaggregating this overall trend by gender, social group and residential status (rural/urban) it is clear that the private school enrolment has gone up for every group - male, female, rural, urban as well as Scheduled Caste8 (SC) and Scheduled Tribe (ST) children (Table 2).

Table 2: Change in enrolment and private school participation of 8 Year Olds In 2002 and 2009

Detailed analysis on the shifts in school population between round one and three undertaken by Woodhead et al (2013) reveal that though private schooling is predominantly urban, expansion has been most rapid in rural areas with private school enrolment effectively trebling between 2002 and 2009. The most financially and socially advantaged (categorised as 'Other Castes'), constitute the largest group accessing private schools with a $25 \%$ increase and make up $70 \%$ of all private school students. Enrolment of children from 'backward classes', is also on the rise and doubled albeit from a lower starting point. However, consistent with the findings of Harma (2011), while LFPS are clearly accessible to the poor they are not necessarily so for the poorest. Young Lives research indicates that gender, location and socio-economic status, number, spacing and gender of siblings all impact upon probability of attending private schools giving rise to equity concerns (Woodhead et al,

\footnotetext{
${ }^{8}$ The Scheduled Castes (SCs), also known as the Dalit, and the Scheduled Tribes (STs) known as Adivasis are two groupings of disadvantaged people that are given express recognition in the Constitution of India
} 
2013). Overall the recent dramatic growth in the private sector has been fuelled by a disproportionate number of boys from the wealthier and more socially advantaged households.

\section{Student Movement \& School Size}

If education is viewed as a system comprised of two sub-systems (private and government provision), then it is clear that student migration from one sub-system will impact on the other. To date this dynamic and its potential impact has received limited attention in the research literature. Potential impacts could feasibly be positive or negative. For example student migration to private schools could be expected to improve student teacher ratios and enable rises in per child expenditure on learning materials for those remaining in the government system - potentially creating improved conditions for meaningful learning. Conversely, large scale movements from the private to the government sector can jeopardise the economic viability of private schools as their fee base is eroded at a faster pace than fixed costs can be reduced (Bangay, 2005).

Young Lives school survey sub-study which investigated existing quality of schooling on a subset of 250 schools (public and private), where 953 YC aged 8-9 years were studying, has revealed that there exists a striking contrast in size between Government and private schools (Singh \& Sarkar, 2012). The analysis shows around half the government schools have fewer than 60 students enrolled at primary level, while only 5.5 per cent have more than 250 students at primary level (Grades 1-5). In contrast, less than one per cent of private schools had fewer than 60 students and over half had more than 250 students.

If the current flow of students from government to private schools continues, particularly in the light of the $25 \%$ reservation clause for economically weaker section students in private schools (as mandated in the Right to Education Act, 2009), the likely future scenario is of falling rolls in government schools and an increase in the number of single teacher and two teacher multi-grade government schools ${ }^{9}$. While this could theoretically be turned to an advantage; small schools dependent on multi-grade approaches do not have a strong track record in India (Blum \& Diwan, 2007; Blum 2009). Teacher education in India does little to prepare teachers with the requisite pedagogical skills to address diverse needs with multigrade classrooms (Joshi, 2009; Singh \& Sarkar, 2012). Often the critical foundation years in the lower grades are neglected, with teachers focusing on students in the higher grades.

\footnotetext{
${ }^{9}$ RTE norms stipulate one teacher to every 30 students.
} 
Young Lives research is consistent with findings from previous studies (De et al., 2002; Mehrotra and Panchamukhi, 2007; Rangaraju et al, 2012) that girls are less likely to attend private schools than boys and socio economically disadvantaged SC and ST children have the lowest participation rate in private schools. As Harma (2009 p. 151) summarises: ' .. poverty is still a bar to the majority, ' with caste, religion, gender, sibling composition, parental age, education and occupation also playing a role'. This phenomenon is further corroborated by Fennel \& Mallik 2012, who reflect that better-off households are benefiting more than the poorer households from the higher quality education provided by low-fee private schools. On scrutinising existing research evidence, the current dynamic between private and government schools does not appear to be delivering favourable benefits for the poorest. If the migration trend from government to private continues then there is a real danger of the entrenchment of an education system differentiated by ability to pay - with children from the most disadvantaged families consigned to poorly performing government schools - which may further be caught in a downward spiral of performance.

\section{Part Four: Implications at Source: Household Finances, Debt Burden and Decision Making}

To date the bulk of research on low-fee private schools has focused on enrolment and relative performance. Less attention has been paid to how the costs of low fee private schools impact on household incomes and decision making. Based on Round 2 (2006) Young Lives data, Himaz (2009) highlighted that educational expenditure per child takes up 6.5 percent of the monthly household expenses, with roughly 37 percent spent on books, 26 percent spent on school fees, 24 percent spent on uniforms, 6 percent on tuitions and 5 percent on transportation. Using Round 3(2009) Young Lives data, an analysis of household expenditure across various educational components such as fees, uniform, books and transport for all children aged 5- 17 years, reveals that households sending children to private schools spend $7.5 \%$ of yearly per capita household expenditure on education as against $2.7 \%$ of total household expenditure for those sending children to public schools ${ }^{10}$. In short, households opting for private schooling are spending two-and-a-half times more on

\footnotetext{
${ }^{10}$ For analysing the household level expenditure we only analyse the educational expenditure of 2458 households, where all children are attending either public or private school
} 
education than those choosing government schools. This huge differential in education expenditure between households opting for government or private schools may well be one of the reasons that $17.6 \%$ of the Younger Cohort children had already changed school once or more since Grade 1, often moving from one private school to another (Singh, 2013). In urban areas this is even more pronounced, with $81 \%$ of the students changing one private school for another by the age of 8 (Woodhead et al, 2012).

The Young lives household questionnaire includes a question on per child spending on combined 'tuition and school fees ${ }^{11}$ It is important to note that while school fee is not charged in public schools at elementary level, children do attend tuition classes, at a cost. There are various models of tuition centres- some private schools run tuitions within the school itself before and after school hours, while others are run by individuals (after school hours) in their homes, both in rural villages and urban slums. This analysis enables us to explore equity issues between the private and government sub-sectors; make preliminary observations on the possible impact that paid tuition may be having within the government sub-sector, and speculate on the potential impact of private school growth on family debt burden.

\section{Private School Enrolment and Household Wealth}

Young Lives data from 2905 households in Round 3 survey conducted in 2009-10, reveals that annual average expenditure on school fees and tuition per child enrolled in private schools is significantly more expensive ${ }^{12}$. What is particularly alarming is the magnitude of that difference. The costs incurred for a primary school child enrolled in private school are some 38 times those going to government schools. At secondary level, the differential is over 18 times (Singh, 2011).

Further analysis of enrolment by wealth quartiles (Figure 5) shows that, private school enrolment increases with wealth for both the age groups. Overall, Young Lives research indicates that 'school choice' is largely enabled by wealth and social status, with children from the top wealth quartile being five times more likely to be enrolled in private schools at elementary level and ten times more likely to be enrolled at the secondary level, as compared

\footnotetext{
${ }^{11}$ Young Lives asked a question on how much is spent on Index child on both tuition and fees from caregivers. We do not have data in the household questionnaire that reveals how many children are taking tuition.

${ }^{12}$ Since public schools do not charge any fees at elementary level, the expenditure for $Y C$ enrolled in public schools, reflects the money spent on private tuitions
} 
to children from the poorest quartile Significantly, in the top wealth quartile $86 \%$ of the younger cohort and $71 \%$ of the older cohort are attending private school, rates that are more than 5 times those amongst the poorest quartile at primary level and 10 times at secondary level.

\section{Figure 5: Wealth quartile wise private school participation in 2009}

Perhaps less obvious, is that this analysis reveals the disparities that exist in household expenditure both within and amongst the private and government school categories. Table 3, provides the average (mean) expenditure for 8 year (primary) and 15 year old (secondary) Young Lives children studying in public and private schools by wealth quartiles. This expenditure is a composite of both school fees and extra tuition spent on an index child annually. The richest quartile sending children to public schools spent almost 13 times the amount on education expenses ${ }^{13}$ as compared to the poorest quartile at primary level. Considering that public schools do not charge fees, the difference can be accounted to the money spent by better -off families on tuitions.

Across all quartiles and for both age groups studying in private schools, educational expenditure is significantly higher. Within the private school sector, the richest quartile is observed to spend 1.7 times higher at primary and twice as much at secondary level when compared to the poorest quartile. This highlights the variance in fees charged by schools within the private school sector.

Table 3: Average annual expenditure (in Rupees) spent on school and extra tuition fees for index child

Given this huge differential in educational expenditure between households opting for public and private schools, it is not surprising that many of the Young Lives children have changed schools from private to public as well as private to private. In 2009/10, 17.6 percent of the younger cohort children aged seven/eight years, had already changed school once or more since first grade (Woodhead et al, 2012). The fact that private schools remain largely unregulated and can increase fees any time, might further explain the reason that few parents

13 Educational expenses in government school at primary level consists primarily of after school tuition fees alone, as government school are free of cost 
may be forced to choose cheaper options, while others may choose what they perceive as 'better' more expensive options if they are economically strong.

Young Lives qualitative interviews with caregivers reveal that even the poorest families have aspirations to send their children to private schools, since they believe that is the only means for their children to move out of the cycle of poverty.

Jayanthi is 8 years old, studying in $3^{\text {rd }}$ Grade in a rural public school and her father is keen to educate her till Grade VII. Jayanthi attends tuition in the evening for which her father pays Rs $30^{14}$ per month and she accompanies her parents to the fields and helps mother in the housework. The father complains that because the groundnut crop failed, he and his wife have taken up daily wage labour work (Rs 60 per day for men and Rs 50 for women) and have had to borrow money from the local Self Help Group. He shares 'we don't have capacity to admit Jayanthi in a private school... we have no capacity to pay... we have to pay Rs.10,000 (per annum) if it is a private residential school... so we admitted our children in a government school. We do not want them to work like us... they should be educated preferably in private schools'.

Parental perception regarding school choice was highlighted by Singh and Sarkar, 2013. While a miniscule 6 percent of parents cited 'good quality' and $53 \%$ cited 'proximity to home' as reasons for choosing government schools, 63\% of parents of children attending private schools cited 'good quality and $23 \%$ cited 'proximity to home' as reasons for school choice. Thus parents are seen to be choosing fee-charging private schools over no-fee charging government schools since good quality teaching is associated with private schools. Also the Young Lives school study highlights that private schools have a higher accountability towards the parents who are making huge sacrifices to pay the school fees and the services are demand-based (Singh \& Sarkar, 2013). Private schools are able to dismiss teachers who are non-performing and a close watch is kept over classroom transactions, while this is not the case in government schools, where the staff is 'permanent' and no robust appraisal system exists. It is pertinent to mention the observation of one of the district education officer regarding government schools "...mainly the teachers of primary school are absent at work. This is due to insufficient monitoring of primary schools."

${ }^{14} 30$ cents 


\section{Private Tutoring}

Young Lives research also highlights the importance of additional tutoring to educational expenditure - a cost that applies to parents of children at both government and private schools. Moreover, while there are large differentials between private and government subsectors there is also price point differentiation in access to services amongst students within each sub-sector.

Understanding of the extent and nature of private tutoring is limited. Bray \& Lykins (2012), estimate that in West Bengal, India, nearly $60 \%$ of primary school students receive private supplementary tutoring. Aslam and Atherton (2012), using 2007-08 data from the School Tells survey of over 4000 students in grades two and four from the north Indian states of Uttar Pradesh and Bihar found nearly a fifth of all children surveyed (i.e. about 20\%) were taking private tuition - though they note these are likely to be under-estimates given private tuition is generally more prevalent in urban areas (Bray 2009). A survey by the Associated Chambers of Commerce and Industry of India (ASSOCHAM, 2013) has revealed that 87 per cent of primary school and 95 per cent of high school students in metros receive private tutoring and that the tuition industry has grown by 35 percent in the period 2006-2013.

Aslam and Atherton (2012) go on to explore the critical question of the extent to which private tutoring is a complement' to or a 'substitute' for poor quality state schooling. They find within both Indian and Pakistani government schools, it is the poorest students who gain the most from tutoring- learning equivalent to $85 \%$ of a school year for India. They state "such large learning differences between those who undertake tuition and those who don't suggest that while there may be equity concerns if the poorest are simply priced out of the private tutoring market, those who do chose to take tuition can compensate for low quality schooling provided in government schools".

Young Lives qualitative interviews also reveal that even the poorest families whose children are studying in government schools are opting for private tuitions, in the hope that their children will learn after school.

Rahul is studying in Grade 4 in a rural government school. His mother shares 'Rahul attends private tuition from 6 a.m. to 8 a.m. after which he takes a bath and goes to school. In the evening he again goes for tuition from 4 p.m. to 6 p.m. We pay Rs.20 per month for our younger daughter and Rs. 30 for Rahul .... we have to pay on the $1^{\text {st }}$ on every month. Tuition fees are increasing from first class to second class... I want 
him to study well. We want him to become a policeman... we have 2 acres of land, so we will sell one acre and spend on his education, so that future will be good.'

However, there are costs associated with tuitions which cause additional financial burden. Qualitative evidence from Young lives research does indicate that cost is a barrier to accessing tuition fees as the transcript below illustrates:

Govind studies in Grade V in a government school and his sister is enrolled in the same school in Grade 2. During school days he also attends tuitions in the school premises itself. The tutor is Mr. Anand who is from this village. During school days, the tuition timings are 4 p.m. to 6 p.m. The family has to pay 40 rupees for Govind and 20 rupees for his younger sister. According to Govind many of the $3^{\text {rd }}$ class students are not attending tuition because of lack of money. Out of a total of 35 students in the school only 20 students can afford the tuition.

The issues of equity within the government school sector in relation to private tuition are largely unresearched, but given the likely extent of private tuition are critically important. Aslam and Atherton (2013) find that in India, private tuition increases with age for wealthier groups and there is evidence of a pro-male gender bias - this being more pronounced among the poorer households. In addition to the effects a critically important question to explore is who is doing the tutoring? If tuitions are being taken by practicing teachers - this would not only go against the stipulation of the Right to Education Act, 2009 which bans teachers from taking tuitions, but is likely to have serious repercussions on quality of education in terms of commitments to all students (and not just those taking additional tutoring). Also given the heterogeneity of tuition services, it would be necessary to study both the quality and utility of the same.

\section{Private Education and Loan Burden}

The Indian government's National Sample Survey Organisation estimates that 43.2 million farmer households, constituting nearly half of all households in India, are indebted to either formal, informal or both sources of credit (NSSO, 59th Round). The highest percentage of indebtedness amongst families is in Andhra Pradesh (82 per cent) which also has the highest incidence of borrowing from moneylenders (57 out of 100 indebted households). Andhra Pradesh is not alone in having high levels of indebtedness, since the states of Tamil Nadu, 
Punjab, Kerala, Karnataka, Maharashtra, Haryana, Rajasthan, Gujarat and West Bengal also have indebtedness rates of over $50 \%$. A report by the Commission on Farmer's Welfare emphasised that in Andhra Pradesh 'skyrocketing health and education expenditures are driving the farmers into deeper debt traps, among other causes of rural indebtedness' (Government of Andhra Pradesh, 2005, p 111). The report further elaborated that private expenditure on education, reflects the combination of changing aspirations of the rural population as well as the inadequacy of the public education system and the lack of access of the rural poor, to the better public educational institutions.

The Young Lives household data reveals that 34 percent of households had taken debt in 2009, with maximum number of households in Quartile 2 and 3 reporting debts (Table 4).

\section{Table 4: Percentage of households reporting debt (by wealth quartile)}

While Young Lives does not profess to have strong evidence on levels on education related debt, its interviews with sample households do suggest this is an important issue. Currently the Young Lives data set is unable to quantify the prevalence, extent, or consequences of school fee related debt burden on household decision making. However, it is clear from the Young Lives qualitative interviews that poor parents are taking on substantial loans, viewing education as the best route to social mobility -an escape from the repressive caste system.

As a Young Lives mother who is a housewife and has one daughter explained:

"People are not worried about their economic background or financial position now madam. They are only bothered about their children's education. They are prepared to give up anything for the sake of their children's education. They want to give their children whatever they missed in their childhood and they want their children to attain that position which they failed to get. That is what parents are thinking now. Moreover, we too are of the same opinion".

The mother goes on to explain the loan burden the family is experiencing:

"We have to raise money somehow and pay her school fees and later on try to clear the incurred loans. ... This is very burdensome. We will not have any savings as we spend everything on education. Strictly speaking, even people of our status cannot afford these schools. Now we have to send our child to even lower rung [private] schools ... the difference in the fees between [the] two types of schools ranges from 5,000 to 10,000 [rupees] and the quality of education offered is very different." 
Unsurprisingly, the poorest are ill placed to provide the collateral, to enable them to secure credit from reputable credit providers. Thus they are more likely to call on informal money lenders infamous for charging usurious rates of interest. With rising educational costs as children move through the system levels of indebtedness are likely to grow and trade-offs on family expenditure become more acute. As another mother notes:

“... loans will remain pending... interest on them would be increasing... but my husband says that even if we don't have (enough)to eat, he wants to educate (the children) We remained illiterate... if they study well, they will become well to-do'.

The impact of school expenditures on household incomes has received little attention. However its possible level of seriousness is illustrated by the fact that Andhra Pradesh has been plagued by farmer suicides - over 3,000 between 2002 and 2007. While the ultimate causes that lead to farmers taking their lives are the financial distress resultant from crop failures, education costs along with dowry do appear in the literature as proximate causes (Chindarkar, 2007; Vidyasagar \& Chandra, 2003). More recently a study into the reasons for the high level of suicides conducted by the Collector of the District of Ananthapur in Andhra Pradesh ranked the reasons for suicide as firstly, debt against loans for agricultural needs; secondly for borrowing against funerals and weddings and thirdly borrowing for education $\operatorname{costs}^{15}$.

\section{Conclusion}

Research on low fee private education has come a long way since the pioneering work of Tooley and Dixon. Private provision in its many guises is an important phenomenon providing schooling to millions of students in emerging nations. As such the low fee private sector warrants further research to strengthen our knowledge base and enable informed decision making, since a variety of development partners are seeking to offer effective support of low fee private schooling. This paper has focused on the impact of private provision in two main areas; impact at source, i.e. the family unit in terms of equity and financial stress and secondly impact at destination, thereby posing questions on how the dynamic between government and private sub-sectors may play out in the evolution of the

\footnotetext{
${ }^{15}$ Personal communication
} 
school delivery ecosystem. These are important questions that Young Lives will continue to explore in subsequent research rounds.

There are of course other areas which warrant urgent attention, such as questions related to financial sustainability and conditions under which low fee private schools are able to deliver quality education. A recent study of 200 low fee private schools in Hyderabad, concluded that low fee private schools charging below Rupees 400 per month lacked the resources to create conducive learning environments and were for the most part financially unsustainable (Gray Matters Capital, 2012). Parental aspirations for ensuring a better future for their children seems to be taking precedence as far as family decisions regarding school choices is concerned. Parental perception of enhanced school quality in 'English medium' private schools is causing a large migration of rural and poor children from government schools. As a recent DFID funded multi-study evidence review concludes low fee private schooling is not a panacea (Barakat et al, 2013). In the absence of mitigation measures, low fee privates can exacerbate inequity both within the school system and within the family unit. Conversely, it is also clear for the most part that parents are not choosing to send their child to school on the basis of whether the school is private or government but whether it is delivering learning. Though better than government schools, recent Young lives studies have shown that private school quality is also suspect, since no quality assurance mechanism currently exists for both private and government schools. To a large extent, the variance in learning performance between government and low fee private schools can largely be accounted for by teacher effectiveness - in crude terms private school teachers turn up more regularly, correcting homework and providing feedback to students and have higher overall levels of self-efficacy, despite lower rates of pay (Singh and Sarkar, 2012). It is time that public policy turns its attention to ensuring that the Right to Education Act, 2009 is realized in both letter and spirit, and regulatory mechanisms and benchmarks for both private and public schools are developed for addressing the governance deficit that currently exists for mentoring and monitoring all schools. Furthermore, given the evidence of growing education debt burden, it is necessary to ensure that arbitrary fee hikes in private schools are checked and monitored by a competent authority.

In conclusion, though it is important to recognize that low fee private schools are not a fix all - this does not mean private sector engagement in education should be written off. Private schools serving the poor should be treated as an integral part of achieving the objective of basic Education for All (Heyneman \& Stern, 2013). While the state must ultimately be the 
arbiter of quality and equity and set quality standards across all types of schools, it does not follow that it must be the only delivery agent. There are a number of interesting public private partnership models, and approaches to cost effective educational delivery in challenging circumstances such as slums, which may hold promise (Bangay and Latham, 2013).

A better understanding of the dynamics within the whole education system comprising both government and non-government providers is going to be critical in planning for equitable and system wide improvement. In this regard, research such as that undertaken by Young Lives, has an important part to play in answering critical questions related to equity in education, within an increasingly marketised education sector. 


\section{References}

Aslam, M. \& Atherton, P. (2012) The Shadow Education Sector in India and Pakistan: Opening Pandora's Box, forthcoming 2014.

Aslam, M. \& Atherton, P. (2013) Private tutoring and student learning: a cross-country analysis, Mimeo (Institute of Education, University of London).

Aslam, M., Kingdon, G., De, A. \& Kumar, R. (2010) Economic returns to schooling and skills: an analysis of India and Pakistan. In Education Outcomes and Poverty in the South ( Ed C. Colclough), London: Routledge.

Annual Status of Education Report (ASER) (2010) Pratham Foundation Accessed from: http://www.pratham.org/aser-report/

Annual Status of Education Report (ASER) (2011)Pratham Foundation Accessed from: http://images2.asercentre.org/aserreports/ASER_2011/india.pdf

Annual Status of Education Report (ASER) (2012) Rural Findings, Pratham Foundation Accessed from:

img.asercentre.org/docs/.../ASER\%20Reports/ASER_2012/nationalfinding.pdf

Bangay, C. (2005) 'Private education: relevant or redundant? Private education, decentralisation and national provision in Indonesia', Compare: A Journal of Comparative and International Education, 35: 2

Bangay, C. (2007) Cinderella or Ugly Sister? : What role for Non-State Education Provision in Developing Countries? In P. Srivastava \& G. Walford. Private Schooling in Less Economically Developed Countries: Asian and African perspectives, Symposium Books

Bangay, C \& Latham, M. (2013) Are we asking the right questions? Moving beyond the state vs non-state providers debate: 'Reflections and a Case Study from India', International Journal of Educational Development, Vol 33, Issue 3, Pages 244-252

Barakat, S., Hardman, F., Rohwerder, B.\& Rzeszut, K. (2013) The evidence for the sustainable scale-up of low-cost private schools in South West Asia. London: EPPI-Centre, Social Science Research Unit, Institute of Education, University of London.

Blum, N. and Diwan, R. (2007) Small, Multigrade Schools and Increasing Access to Primary Education in India: National Context and NGO Initiatives. CREATE Pathways to Access Research Monograph No. 17. Delhi/London: NUEPA/ Institute of Education

Blum, N. (2009) Small NGO schools in India: implications for access and innovation. Compare Vol. 39 (2) 
Bray, M. \& Lykins, C. (2012) Shadow education: Private supplementary tutoring and its implications for policy makers in Asia. Philippines: Asian Development Bank.

Bray, M. (2009). Confronting the Shadow Education System: What Government Policies for What Private Tutoring?, UNESCO Publishing, IIEP Policy Forum, International Institute for Educational Planning, Paris, France.

Chavan, M. \& Bannerji, R. (2012) The Challenge of Achieving Desirable Levels of Learning in Elementary Education, Journal of Governance, Accessed from: pratham.org/file/Banerji_Chavan-Journal-of-Governance-July-2012.pdf

Chindarkar, N. (2007) A Comparative Analysis of Farmers' Suicides in Andhra Pradesh, India. Methodological Innovations Online (2007) 2(2) 6-19. Accessed from: www.pbs.plym.ac.uk/mi/pdf/.../2.\%20Chindarkar\%20formatted\%206-19.pdf

Chudgar, A. \& Quin, E. (2012) Relationship between private schooling and learning: Results from rural and urban India, Economics of Education Review, 31(4), 376-39

Commission on Farmer's Welfare (2005) Report of the Commission on Farmer's Welfare, Government of Andhra Pradesh. Accessed on 26 Jan 2014, http://www.macroscan.org/pol/apr05/pdf/Full_Report_Commission_Farmer_AP.pdf

CREATE. (2009) Educational Access in India; Country Policy Brief. Consortium for Research on Education, Access, Transitions and Equity, University of Sussex

De, A., Majumdar, M., Samson, M., \& Noronha, C. (2002) Private Schools and Universal Elementary Education, in Govinda, R. (ed.) India Education Report: A Profile of Basic Education, Oxford and New Delhi: Oxford University Press, pp. $131-150$.

De, A. (2011) Probe Revisited: A Report on Elementary Education. Oxford University Press, New Delhi

Desai, S., Dubey, A., Vanneman, R., and Banerji, R. (2008) Private schooling in India: A new educational landscape. In India Policy Forum, volume 5, 1-58. Global Economy and Development Program, The Brookings Institution.

DISE (2011). Elementary Education In India, Flash Statistics, District Information System for Education, National University of Educational Planning \& Administration, New Delhi

Education Initiatives (2006) Student Learning in Metros Study, Accessed from: http://www.ei-india.com/wp-content/uploads/2012/07/Student-Learning-in-the-Metros-Issue2.pdf

Education Initiatives (2010) Quality Education Study. Accessed from: http://www.ei-india.com/wp-content/uploads/2012/07/Executive_Summary-Low_ResolutionQES1.pdf Full report available at http://www.ei-india.com/quality-education-study-qes/]

Fennell, S \& Malik, R. (2012) Between a rock and a hard place: the emerging educational market for the poor in Pakistan, Comparative Education, Vol. 48, No. 2, 249-261 
French, R. and Kingdon, G. (2010) The relative effectiveness of private and government schools in rural india: Evidence from ASER data. DoQSS Working Paper 1003, Institute of Education, UK

Galab, S., Kumar, V., Reddy, P., Singh, R. \& Vennam, U. (2011) The impact of growth on Childhood Poverty in Andhra Pradesh, Round 3 Survey Report, Young Lives, Oxford.

Govinda, R., \& Varghese, N. (1993) Quality of Primary Schooling in India: A Case Study of Madhya Pradesh, International Institute for Educational Planning, National Institute of Educational Planning and Administration

Goyal, S. (2009) Inside the house of learning: the relative performance of public and private schools in Orissa, Education Economics, 17:3, 315-327.

Goyal, S., \& Pandey, P. (2009) How do government and private schools differ: Findings from two Indian states, South Asia Human Development, World Bank

Gray Matters Capital ( 2012) Affordable Private Schools Sector Analysis Report. Accessed from: www.periglobal.org/.../APS\%20Sector\%20Analysis_2012_GrayMattersCapital.pdf

Harma, J. (2009) Can choice promote Education for All? Evidence from growth in private primary schooling in India, Compare, 39 (2), $151-165$.

Harma, J. (2011) Low cost private schooling in India: Is it pro poor and equitable? International Journal of Education and Development 31 (4), 350-356.

Heyneman, S.P. \& Stern, J.M.B. (2013) Low cost private schools for the poor: What public policy is appropriate? International Journal of Educational Development, 35, March 2014, 3 15.Accessed from: http://dx.doi.org/10.1016/j.ijedudev.2013.01.002

Himaz, R (2009) Is there a boy bias in household education expenditure? The case of Andhra Pradesh in India based on Young Lives data, Working Paper 46, Young Lives, University of Oxford

Kingdon, G. (1996) The quality and efficiency of public and private schools: A case study of urban India. Oxford Bulletin of Economics and Statistics 58, no. 1 (Feb.): 55-80.

Kingdon, G. (2006) Teacher characteristics and student performance in India: A pupil fixed effects approach. GPRG-WPS-059, Global Poverty Research Group, Department of Economics, University of Oxford.

Kingdon, G. (2007) The progress of school education in India, Global Poverty Research Group. Accessed from http://www.gprg.org/pubs/workingpapers/pdfs/gprg-wps-071.pdf

Kingdon, G. (2010) The implications of the Sixth Pay Commission on Teacher Salaries in India, RECOUP Working Paper 29, University of Cambridge. 
Kumra, N. ( 2008) An Assessment of the Young Lives Sampling Approach in Andhra Pradesh, India, Young Lives Technical Note No. 2 , Young Lives, Oxford, UK

Latham, M. (2013) Personal correspondence.

Little, A. (2010) Access to Elementary Education in India: Politics, Policies and Progress, CREATE, Monograph No:44, University of Sussex

Mehrotra, S.\& Panchamukhi P. R. (2007) "Universalising Elementary Education in India: is the Private School the Answer?" in P. Srivastava \& G Walford (Eds) Private Schooling in Less Economically Developed Countries: Asian and African Perspectives., Oxford: Symposium Books.

Ministry of Human Resource Development (2013) Right to Free\& Compulsory Education Act, 2009. Accessed from: http://mhrd.gov.in/rte

Muralidharan, K., \& Kremer, M. (2006) Public and Private Schools in Rural India, Department of Economics, Harvard University. Accessed from: http://citeseerx.ist.psu.edu/viewdoc/download?doi=10.1.1.168.3057\&rep=rep1\&type=pdf

Nilekani, N. (2010) Imagining India: The idea of a Renewed Nation, Penguin Books.

Noronha, C., \& Srivastava, P. (2012) The Right to Education Act in India: focuses on early implementation issues and the private sector. Report submitted to the Privatisation in Education Research Initiative (PERI), Open Society Foundation

National Sample Survey (2003) Indebtedness of Farmer Households, $59^{\text {th }}$ Round, Report 498. Accessed from:

http://planningcommission.nic.in/sectors/agri_html/Indebtness $\% 20$ of\%20farmer\%20househol d\%2059\%20round\%202003.pdf

Pritchett, L. \& Beatty, A. (2012) The Negative Consequences of Overambitious Curricula in Developing Countries, Centre for Global Development Working Paper 29. Accessed from: www.cgdev.org/negative-consequences-overambitious-curricula-developing-countriesworking-paper-293

Rangaraju, B., Tooley, J.\& Dixon, P. (2012)The Private School

Revolution in Bihar: Findings from a Survey in Urban Patna, Delhi: India Institute.

Seventh Annual Survey of Education Report (2011) Annual Status of Education Report (ASER), Pratham, New Delhi.

Singh, R. (2011) 'Is Better Good Enough? Privatisation of education and its links to inequity and gender bias', Conference paper presented at 'Education for Rural Transformation (ERT): Good Practices from National and International Perspectives', Vadodara, India 
Singh, R., \& Sarkar, S. (2012) Teaching Quality Counts: How Student Outcomes Relate to Quality of Teaching in Private and Public Schools in India, Working Paper 9, Young Lives, University of Oxford.

Singh, R (2013) Need for Systemic Reform in Education: Ensuring Poorest Children Are Not Short-changed, Policy Brief 1, Young Lives, University of Oxford.

Srivastava, P. (2007) ' For philanthropy or profit?' The management and operation of low-fee private schools in India', in P. Srivastava and G. Walford (Eds)Private Schooling in Less Economically Developed Countries: Asian and African perspectives, Symposium Books.

Stern, J. M. B. \& Heyneman S.P. (2012) 'Low fee private schooling : the case of Kenya', in Srivastava, $\mathrm{P}(\mathrm{Ed})$ Low fee private schooling: Aggravating equity or mediating disadvantage. Oxford: Oxford Series in Comparative Education Symposium Books

The Associated Chamber of Commerce and Industry of India (2013) Business of Private Coaching Centres in India, ASSOCHAM, New Delhi.

Tooley, J., \& Dixon, P. (2003) Private Schools for the Poor: A Case Study from India. Reading : CfBT Research and Development.

UNESCO (2012) Education For All Global Monitoring Report, UNESCO, Paris Accesssed from: http://doc.iiep.unesco.org/wwwisis/repdoc/SEM313/SEM313_12_eng.pdf

UNICEF (2011) The Situation of Children in India, UNICEF. Accessed from: http://www.unicef.org/sitan/files/SitAn_India_May_2011.pdf

Vidyasagar, R.M. \& Chandra, K.S. (2003) Farmers' Suicides in Andhra Pradesh and Karnataka, Centre for Social Development, NIRD, Hyderabad.

Wadhwa, W. (2009) Are private schools really performing better than government schools? In Annual Status of Education Report (Rural), ASER 2009. Accessed from: http://asercentre.org/asersurvey/aser09/pdfdata/aser09.pdf

Woodhead, M., Frost, M., \& James, Z. (2013) 'Does growth in private schooling contribute to Education For All? Evidence from a longitudinal two cohort study in Andhra Pradesh, India', International Journal of Educational Development, Vol 33, 65-73, Issue, 1. 